\title{
Sistem Rekomendasi Rumah Berbasis Web Menggunakan Metode SAW pada PT. Inproperty
}

\author{
Sofi Nur Rochmawati ${ }^{1}$, Fitri Marisa ${ }^{2}$ \\ ${ }^{1}$ sofinur_rochmawati@yahoo.co.id, ${ }^{2}$ fitrimarisa@widyagama.ac.id
}

\author{
Program Studi Teknik Informatika, Fakultas Teknik Universitas Widyagama
}

\begin{abstract}
This research is a web based recommendation system. This home recommendation system aims to facilitate the prospective buyer in choosing a home because this system applies ranking on each alternative. The method used is SAW method. Saw methods are used to determine the appropriate variables to be recommended by means of criteria, weighting, and calculation of Saws so as to elicit a normalized matrix. Given the normalized matrix, the final value or ranking in each alternative. The results of the calculation using the Saw method show that the acquisition of A3 (Batu) is the best alternative because it is $83.5 \%$ while the A1 (Tidar) which is $76 \%$ and A2 (Singosari) is the lowest alternative because it is $47.5 \%$. Based on the acquisition can be known appropriate home recommendations for people who want to buy a house.
\end{abstract}

Intisari-Penelitian ini berupa sistem rekomendasi rumah berbasis web. Sistem rekomendasi rumah ini bertujuan untuk mempermudah calon pembeli dalam memilih rumah karena sistem ini menerapkan perangkingan pada setiap alternatif. Metode yang digunakan yaitumetode SAW. Metode saw digunakan untuk menentukan variabel yang tepat untuk direkomendasikan dengan cara pemberian kriteria, pemberian nilai bobot, dan dilakukan perhitungan saw sehingga memunculkan matriks ternormalisasi. Dengan adanya matriks ternormalisasi didapatkan nilai akhir atau perangkingan pada setiap alternatif. Hasil perhitungan dengan menggunakan metode SAW menunjukkan perolehan A3(Batu)merupakan alternative terbaikkarenamemperoleh sebesar $83,5 \%$ sedangkan A1 (Tidar) yang memperoleh sebesar $76 \%$ dan A2 (Singosari) merupakan alternatif terendah karena memperoleh sebesar $47,5 \%$. Berdasarkan perolehan tersebut dapat diketahui rekomendasi rumah yang tepat bagi orang yang hendak membelirumah.

Kata Kunci- Sistem Rekomendasi, Metode SAW, Perhitungan SAW.

\section{PENDAHULUAN}

Berkembangnya teknologi membuat informasimenjadi mudah untuk dicari tanpa adanya usaha yang banyak untuk mencari sebuah informasi[1].Masalah yang sering dihadapi pada perusahaan khususnya di bidang property yaitu sistem konvensional dalam pemasaran[2],sedikitnya wadah untuk memposting iklan penjualan rumah, banyaknya ketentuan dalam posting iklan seperti 1 akun hanya dapat memposting 3 rumah yang akan dijual dalam kawasan Jawa Timur ataupun kawasan daerah lainnya. Kata dalam setiap postingan harusberbeda.

Dengan adanya ketentuan seperti itu membuat karyawan di bidang marketing pada perusahaan property harus membuat akun minimal 10 agar iklan perusahaan tersebut dapat terus berada di bagian atas, sehingga pembeli dapat melihat pertama pada iklan rumah. Akan tetapi menjadi kurang efisien dalam penggunaan email karena pada bagian marketing diharuskan membuat email secara terus menerus dan akhirnya email lama yang dibuat tidak terpakai[3].

Dengan adanya sistem rekomendasi rumah, bagian tim marketing tidak perlu membuat akun yang berlebihan, cukup dengan 1 akun. Hasil dari sistem rekomendasi rumah ini dapat diketahui bahwa nilai alternatif tertinggi diperoleh pada daerah Batu yang memperoleh sebesar 83,5\% dan alternatif terendah diperolehpadadaerahSingosariyangmemperolehsebesar47,5\% dari kriteria harga, tipe rumah, luas tanah, dan fasilitas yang diberikanolehperusahaanproperty.Dariperolehantersebutdapat diketahui rumah dengan kualitas yang terbaik.Sehingga sistem rekomendasi ini memudahkan bagi calon pembeli yang mencari rumah.

\section{TINJAUANPUSTAKA}

\subsection{Sistem Rekomendasi}

Sistem rekomendasi adalah sebuah sistem yang dapat memberikan rekomendasi kepada para pengguna sistem yang akan dibuat[4].Sedangkan dalam mengumpulkan data untuk pembuatan sistem rekomendasi dapat dilakukan secara langsung dan tidak langsung. Pengumpulkan data secara langsung dapat dilakukan sebagai berikut:

1. Meminta user untuk melakukan rating pada sebuah item.

2. Meminta user untuk melakukan rangking pada item favorit setidaknya memilih satu item favorit.

3. Memberikan beberapa pilihan item pada user dan memintanya memilih yang terbaik.

4. Meminta user untuk mendaftar item yang paling disukai atau Item yang tidak disukainya.

Pengumpulan data dengan tidak langsung berhubungan dengan seorang user, dilakukan dengan cara mengamati item 
yang dilihat oleh seorang user pada sebuah webe-commerce. Dari data hasil yang dikumpulkan tersebut, kemudian diolah dengan menggunakan algoritma tertentu. Setelah itu, hasilnya tersebut dikembalikan lagi kepada user sebagai sebuah rekomendasi item dengan parameter dari user tersebut. Sistem rekomendasi juga merupakan salah satu alternatif sebagai mesin pencari suatu item yang dicari oleh user[5].

\subsection{Metode SAW}

Metode SAW dikenal dengan istilah metode penjumlahan terbobot dari rating kinerja pada setiap alternatif pada semua atribut[6]. Metode SAW membutuhkan proses normalisasi matriks keputusan $(X)$ ke suatu skala yang dapat diperbandingkan dengan semua rating alternatif yang ada[7].

$\mathrm{r}_{\mathrm{ij}}=\left\{\begin{array}{l}\frac{\underline{X}_{i j}}{\operatorname{Max}_{i} X_{i j}} \text { jka adalah atribut keuntungan } \\ \frac{\operatorname{Min}_{i} X_{i j}}{X_{i j}} j i k a j \text { adalah atribut biaya (1) }\end{array}\right.$

Keterangan:

Max Xij = Nilai terbesar dari setiap kriteria i.

Min Xij = Nilai terkecil dari setiap kriteria $\mathrm{i}$.

$\mathrm{Xij}=$ Nilai atribut yang dimiliki dari setiap kriteria.

Benefit $=$ Jika nilai terbesar adalah yang terbaik.

Cost $=$ Jika nilai terkecil adalah yang terbaik .

Dengan rij adalah rating kinerja ternormalisasi dari alternatif Ai pada atribut $\mathrm{Cj} ; \mathrm{i}=1,2, \ldots \mathrm{m}$ dan $\mathrm{j}=1,2, \ldots, \mathrm{n}$. Nilai preferensi untuk setiap alternatif (Vi) diberikan sebagai berikut :

$$
v_{i}->{ }_{j=l^{j}}^{n v} r_{i j}(2)
$$

Keterangan:

$\mathrm{Vi}=$ Nilai akhir dari alternatif

wj = Bobot yang telah ditentukan

rij = Normalisasi matriks

Nilai Vi yang lebih besar mengindikasikan bahwa alternatif Ai lebih terpilih.

\subsection{Cara Penyelesaian SAW}

Dalam penelitian ini menggunakan metode SAW. Langkah-langkah pemecahan masalah dalam penelitian ini adalah sebagai berikut:

1. Menentukankriteria-kriteriayangakandijadikanacuandalam menentukan pengambilan keputusanCj.

2. Memberikannilaisetiapalternatif(Ai)padasetiapkriteria(Cj) yang sudah ditentukan, dimana nilaii $=1,2, \ldots \ldots$.

3. Menentukan rating kecocokan setiap alternatif pada setiap kriteria kemudian memodelkannya ke dalam bilangan fuzzy setelah itu dikonversikan kebilangan.

4. Memberikan nilai bobot (W) yang juga didapatkan berdasarkan nilai.

5. Melakukan normalisasi matriks dengan cara menghitung nilai rating kinerja ternormalisasi (rij) dari alternatif $\mathrm{Ai}$ pada atribut $\mathrm{Cj}$ berdasarkan persamaan yang disesuaikan dengan jenis atribut (atribut keuntungan/benefit = MAXIMUM atau atribut biaya/cost = MINIMUM). Apabila berupa atribut keuntungan maka crisp (Xi j) dari setiap kolom atribut dibagi dengan nilai crisp MAX (MAX $\mathrm{Xi}$ j) dari setiap kolom, sedangkan untuk atribut biaya, nilai crisp MIN (MIN Xi j) dari setiap kolom atribut dibagi dengan nilai crisp (Xi j) setiapkolom.

6. Melakukan proses perangkingan untuk setiap alternatif (Vi) dengan cara mengalikan nilai (Wi) dengan nilai rating kinerja ternormalisasi(rij).

7. Menentukan nilai preferensi untuk setiap alternatif (Vi) dengan cara menjumlahkan hasil kali antara matriks ternormalisasi $(\mathrm{R})$ dengan nilai bobot $(\mathrm{W})$. Nilai Vi yang lebih besar mengindikasikan bahwa alternatif $\mathrm{Ai}$ lebih terpilih.

\section{METODEPENELITIAN}

\subsection{Metode Pengumpulan Data}

Penelitian dilaksanakan selama satu bulan di PT.Inproperty Kota Malang, dengan melakukan wawancara kepada pimpinan dan karyawan di PT.Inproperty.

\subsection{Metode Penentuan Variabel Data}

Dalam menentukan variabel data yang digunakan untuk memberikan rekomendasi rumah yang sesuai dan cara menentukan variabel yang dibutuhkan adalah dengan cara mengajukan pertanyaan kepada karyawan PT.Inproperty.

\subsection{Perancangan Sistem}

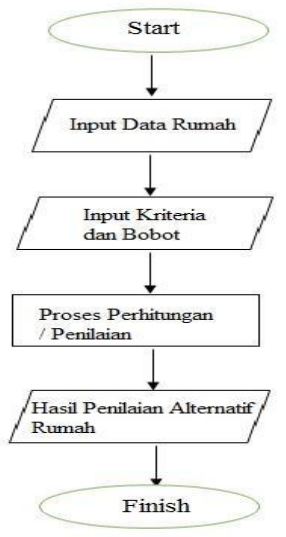

Gambar 1. Flowchart Perhitungan SAW

Dari flowchart perhitungan SAW dapat dijelaskan sebagai berikut:

1. Menginputkan data rumah

2. Kemudian menginputkan kriteria dan bobot yang telah ditentukan.

3. Setelah itu dilakukan proses perhitungan atau penilaian sehingga menghasilkan alternative rumah untuk dijadikan sebagai acuan rekomendasi pada PT.Inproperty. 


\subsection{TahapPengujian}

Pada pengujian, akan menggunakan metode Simple Additive Weighting (SAW) sebagai tahap pengujian atau dengan kata lain tahap perhitungan dan diperlukan kriteriakriteria dan bobot untuk melakukan perhitungannya sehingga akan didapat alternative terbaik. Simple Additive Weighting Method (SAW) merupakan metode penjumlahan terbobot.Konsep dasar metode SAW adalah mencari penjumlahan terbobot dari rating kinerja pada setiap alternatif pada semua kriteria. Metode SAW membutuhkan proses normalisasi matrik keputusan (X) ke suatu skala yang dapat diperbandingkan dengan semua rating alternatif yang ada.

Metode SAW mengenal adanya 2 (dua) atribut yaitu kriteria keuntungan (benefit) dan kriteria biaya (cost). Perbedaan mendasar dari kedua kriteria ini adalah dalam pemilihan kriteria ketika mengambil keputusan. Adapun penilaian alternative yang dinilai ditandai dengan A1 sampai dengan A3, dengan uraian sebagai berikut:

$$
\begin{aligned}
& \text { A1 }=\text { Tidar } \\
& \text { A2 }=\text { Singosari } \\
& \text { A3 }=\text { Batu }
\end{aligned}
$$

\subsection{MenentukanKriteria}

\section{1. $\mathrm{C} 1=$ Harga}

Untuk memberitahukan harga rumah yang dijual dan untuk membandingkan dengan harga rumah lainnya.

2. $\mathrm{C} 2=$ TipeRumah

Untuk memberitahukan tipe rumah yang dijual dan digunakan untuk membandingkan dengan rumah yang lainnya.

3. C3 = LuasTanah

Untuk memberitahukan luas tanah yang dijual sehingga dapat dibandingkan dengan luas tanah rumah dijual lainnya.

4. $\mathrm{C} 4=$ Fasilitas

Untuk memberitahukan fasilitas yang ada pada saat rumah dijual sehingga dapat dibandingkan dengan fasilitas rumah lainnya.

Maka didapatkan tabel nilai bobot kriteria dan kriteria sebagai berikut :

Tabel 1.

Nilai Bobot

\begin{tabular}{|l|l|}
\hline \multicolumn{2}{|c|}{ Bobot Kriteria } \\
\hline Harga & $25 \%$ \\
\hline Tipe Rumah & $35 \%$ \\
\hline Luas Tanah & $25 \%$ \\
\hline Fasilitas & $15 \%$ \\
\hline
\end{tabular}

Tabel 2.

Kriteria

\begin{tabular}{|c|l|}
\hline Kode & \multicolumn{1}{|c|}{ Kriteria } \\
\hline C1 & Harga \\
\hline C2 & Tipe Rumah \\
\hline C3 & Luas Tanah \\
\hline C4 & Fasilitas \\
\hline
\end{tabular}

\section{HASIL DAN PEMBAHASAN}

\subsection{Hasil dan AnalisisData}

Input untuk melakukan proses pengambilan keputusan dari beberapa alternative. Variabel Input yang akan digunakan adalah sebagai berikut:

1. Harga rumah padaPT.Inproperty

2. Tipe rumah yang dijual padaPT.Inproperty

3. Luas tanahrumah

4. Nilai fasilitas yang diberikan pihakPT.Inproperty

\subsection{Pembobotan Alternatif pada SetiapKriteria}

Keluaran yang dihasilkan dari penelitian ini adalah sebuah alternative yang memiliki nilai tertinggi dibandingkan alternative nilai lainnya.Alternatif yang dimaksud adalah hasil akhir dari penilaian rumah untuk dijadikan rekomendasi pada PT.Inproperty.Hasil akhir yang dikeluarkan nanti berasal dari setiap kriteria, karena dalam setiap kriteria mempunyai nilai yang berbeda-beda.Urutan alternative mulai dari alternatif tertinggi hingga ke alternatif terendah. Nilai dari Atribut Alternatif PT.Inproperty diperoleh dari hasil penilaian dari peneliti terhadap rekomendasi rumah ke calon pembeli pada PT.Inproperty setelah melakukan observasi.Hasil penilaian tersebut kemudian dikonversikan berdasarkan tabel bobot dari masing-masing kriteria. Sedangkan nilai dari alternatifalternatif lain, ditentukan oleh peneliti untuk menentukan rekomendasi rumah yang pas pada PT.Inproperty.Terdapatdatarumahawalyangbelumdinormalisas ikan ataudihitunguntukmenentukanrumahyangterbaikdengan atas dasar luas tanah yang sama sebagaiberikut:

Tabel 3.

Data Rumah

\begin{tabular}{|l|c|c|c|c|}
\hline Daerah & Harga & $\begin{array}{c}\text { Tipe } \\
\text { Rumah }\end{array}$ & $\begin{array}{c}\text { Luas } \\
\text { Tanah }\end{array}$ & Fasilitas \\
\hline Tidar & Rp628.000.000 & 67 & $60 \mathrm{~m}$ & 3 \\
\hline Singosari & Rp396.000.000 & 36 & $60 \mathrm{~m}$ & 3 \\
\hline Batu & Rp650.000.000 & 67 & $60 \mathrm{~m}$ & 6 \\
\hline
\end{tabular}

Pertama-tama, data awal rumah pada tabel 3 dilakukan normalisasi matriks $\mathrm{X}$ berdasarkan persamaan (1) sebagai berikut:

Tabel 4.

Normalisasi Matriks X

\begin{tabular}{|c|c|c|c|c|}
\hline \multirow{2}{*}{ Alternatif } & \multicolumn{4}{|c|}{ KRITERIA } \\
\cline { 2 - 5 } & $\mathrm{C} 1$ & $\mathrm{C} 2$ & $\mathrm{C} 3$ & $\begin{array}{l}\mathrm{C} \\
4\end{array}$ \\
\hline A1 & $\frac{396.000 .000}{628.000 .000}$ & $\frac{67}{67}$ & $\frac{60}{60}$ & $\begin{array}{l}3 \\
6\end{array}$ \\
\hline A2 & $\frac{396.000 .000}{396.000 .000}$ & $\frac{36}{67}$ & $\frac{60}{60}$ & $\frac{3}{6}$ \\
\hline A3 & $\frac{396.000 .000}{650.000 .000}$ & $\frac{67}{67}$ & $\frac{60}{60}$ & $\frac{6}{6}$ \\
\hline
\end{tabular}


Maka mendapatkan hasil dari nilai rating kinerja ternomalisasi (rij) dari tabel 4 dan membentuk matrik ternormalisasi (R).

Tabel 5.

Faktor Ternormalisasi

\begin{tabular}{|c|c|c|c|}
\hline $\mathrm{C} 1$ & $\mathrm{C} 2$ & $\mathrm{C} 3$ & $\mathrm{C} 4$ \\
\hline 0,63 & 1 & 1 & 0,5 \\
\hline 1 & 0,54 & 1 & 0,5 \\
\hline 0,61 & 1 & 1 & 1 \\
\hline
\end{tabular}

Dengan matriks ternormalisasi diatas, maka akan mencari nilai prefensi dari setiap alternatif dengan cara menjumlahkan hasil kali antara matriks ternormalisasi dengan nilai bobot setiap kriteria.Berikut merupakan perhitungan nilai preferensi menggunakan persamaan (2) dari setiap alternatif yang telah ditentukan.

Tabel 6.

Bobot Kriteria

\begin{tabular}{|l|l|}
\hline \multicolumn{2}{|c|}{ Bobot Kriteria } \\
\hline Harga & $25 \%$ \\
\hline Tipe Rumah & $35 \%$ \\
\hline Luas Tanah & $25 \%$ \\
\hline Fasilitas & $15 \%$ \\
\hline
\end{tabular}

Maka : $W=\left\{\begin{array}{llll}25 & 35 & 25 & 15\end{array}\right\}$

Hasil yang diperoleh sebagai berikut :

$$
\begin{aligned}
\mathrm{V} 1 & =(0,63 \times 25)+(1 \times 35)+(1 \times 25)+(0,5 \times 15) \\
& =15,75+35+25+7,5 \\
& =83,25 \\
\mathrm{~V} 2 & =(1 \times 25)+(0,54 \times 35)+(1 \times 25)+(0,5 \times 15) \\
& =25+18,9+25+7,5 \\
& =76,4 \\
\mathrm{~V} 3 & =(0,61 \times 25)+(1 \times 35)+(1 \times 25)+(1 \times 15) \\
& =15,25+35+25+15 \\
& =90,25
\end{aligned}
$$

Hasil perhitungan nilai $\mathrm{Vi}$ yang lebih besar mengindikasikan bahwa alternatif $\mathrm{Ai}$ merupakan alternatif terbaik[9]. Hasil penilaian terbesar ada pada $V_{3}$ (Batu) yaitu pada tipe rumah (luas bangunan) dan fasilitas yang diberikan PT.Inproperty, ini dapat sebagai acuan untuk rekomendasi rumah bagi calon pembeli yang bingung memilih rumah yang tepat dan sebagai alternative yang diberikan.

Maka dengan itu dapat diketahui perangkingan rumah dengan luas tanah yang sama. Dan diketahui penilaian yang tertinggi hingga terendah pada tabel 7 , berikut ini:

Tabel 7.

Perankingan

\begin{tabular}{|l|c|c|c|c|c|}
\hline \multirow{2}{*}{ Alternatif } & \multicolumn{5}{|c|}{ Kriteria } \\
\cline { 2 - 6 } & Harga & $\begin{array}{c}\text { Tipe } \\
\text { Rumah }\end{array}$ & $\begin{array}{c}\text { Luas } \\
\text { Tanah }\end{array}$ & Fasilitas & $\begin{array}{c}\text { Hasil } \\
\text { Akhir }\end{array}$ \\
\hline Batu & 15,25 & 35 & 25 & 15 & 90,25 \\
\hline Tidar & 15,75 & 35 & 25 & 7,5 & 83,25 \\
\hline Singosari & 25 & 18,9 & 25 & 7,5 & 76,4 \\
\hline
\end{tabular}

Maka diketahui wilayah Batu rekomendasi rumah paling tertinggi dengan kualitas paling baik dan rekomendasi wilayah terendah adalah wilayah Singosari.

\section{KESIMPULAN DANSARAN}

\subsection{Kesimpulan}

Berdasarkan hasil penelititan yang dilakukan dan hasil pembahasan, dapat disimpulkan bahwa :

1. Dengan adanya sistem rekomendasi rumah ini dapat memudahkan para calon pembeli yang memilih atau mencari rumah karena sistem ini merekomendasikan mulai dari tertinggi hingga terendah, sehingga pembeli dengan mudah melihat atau mencari rumah dengan kualitas yang baik dan dengan sistem ini memberikan efek positif kepada PT.Inpropety karena pembeli merasa puas akan rekomendasi yang diberikan.

2. DenganperhitunganSAWdapatmemudahkanrekomenda si rumah karena perhitungan saw untuk memberikan perankingan dari tertinggi hingga terendah pada setiap alternatif, maka dengan metode saw sangat membantu dalam sistemrekomendasi.

\subsection{Saran}

Untuk penelitian selanjutnya peneliti menyarankan untuk menggunakan metode lain sehingga sistem rekomendasi rumah dapat terus berkembang ke depannya.

\section{DAFTAR PUSTAKA}

[1] I. Darimi, "Teknologi Informasi Dan Komunikasi Sebagai Media Pembelajaran Pendidikan Agama Islam Efektif," J. Pendidik. Teknol. Inf., vol. 1, no. 2, pp. 111$121,2017$.

[2] M. K. Taufani, "ANALISIS DAN DESAIN SISTEM INFORMASI PEMASARAN," Taufani, Moh. Khafid, vol. 38, no. 2, pp. 1-10, 2016.

[3] R. Hurriyati, "Strategi Pemasaran Usaha Kecil Berbasis Web 2 . 0 Sebagai Upaya Dalam Meningkatkan Daya Saing," no. 229, pp. 1-25, 2010.

[4] C. S. E. Prasetya, "Sistem Rekomendasi Pada ECommerce Menggunakan K-Nearest Neighbor," $J$. Teknol. Inf. dan Ilmu Komput., vol. 4, no. 3, pp. 23557699, 2017.

[5] M. I. Fathurrahman, D. Nurjanah, and R. Rismala, "Sistem Rekomendasi Metode Trust-Aware Recommendation Recommendation System for book by using Trust-Aware Recommendation Method," $e$ Proceeding Eng., vol. 4, no. 3, pp. 4966-4977, 2017.

[6] A. P. Windarto, "Implementasi Metode Topsis Dan Saw Dalam Memberikan Reward," Klik - Kumpul. J. Ilmu Komput., vol. 4, no. 1, p. 88, 2017.

[7] N. Ketut and D. Ari, "Implementasi Metode SAW dan AHP pada Sistem Informasi Penilaian," CSRID J., vol. 8, no. 2, pp. 86-98, 2016. 